\title{
Front Matter: Volume 11503
}

, "Front Matter: Volume 11503," Proc. SPIE 11503, Infrared Sensors, Devices, and Applications X, 1150301 (24 September 2020); doi: 10.1117/12.2581589

SPIE. Event: SPIE Optical Engineering + Applications, 2020, Online Only 


\title{
PROCEEDINGS OF SPIE
}

\section{Infrared Sensors, Devices, and Applications $X$}

\author{
Ashok K. Sood \\ Priyalal Wijewarnasuriya \\ Arvind I. D'Souza \\ Editors
}

August 24- 4 September 2020

Online Only, United States

Sponsored and Published by

SPIE 
The papers in this volume were part of the technical conference cited on the cover and title page. Papers were selected and subject to review by the editors and conference program committee. Some conference presentations may not be available for publication. Additional papers and presentation recordings may be available online in the SPIE Digital Library at SPIEDigitalLibrary.org.

The papers reflect the work and thoughts of the authors and are published herein as submitted. The publisher is not responsible for the validity of the information or for any outcomes resulting from reliance thereon.

Please use the following format to cite material from these proceedings:

Author(s), "Title of Paper," in Infrared Sensors, Devices, and Applications X, edited by Ashok K. Sood, Priyalal Wijewarnasuriya, Arvind I. D'Souza, Proceedings of SPIE Vol. 11503 (SPIE, Bellingham, WA, 2020) Seven-digit Article CID Number.

ISSN: 0277-786X

ISSN: 1996-756X (electronic)

ISBN: 9781510638129

ISBN: 9781510638136 (electronic)

Published by

SPIE

P.O. Box 10, Bellingham, Washington 98227-0010 USA

Telephone +1 3606763290 (Pacific Time) · Fax +1 3606471445

SPIE.org

Copyright (c) 2020, Society of Photo-Optical Instrumentation Engineers.

Copying of material in this book for internal or personal use, or for the internal or personal use of specific clients, beyond the fair use provisions granted by the U.S. Copyright Law is authorized by SPIE subject to payment of copying fees. The Transactional Reporting Service base fee for this volume is $\$ 21.00$ per article (or portion thereof), which should be paid directly to the Copyright Clearance Center (CCC), 222 Rosewood Drive, Danvers, MA 01923. Payment may also be made electronically through CCC Online at copyright.com. Other copying for republication, resale, advertising or promotion, or any form of systematic or multiple reproduction of any material in this book is prohibited except with permission in writing from the publisher. The CCC fee code is $0277-$ $786 \mathrm{X} / 20 / \$ 21.00$.

Printed in the United States of America by Curran Associates, Inc., under license from SPIE.

Publication of record for individual papers is online in the SPIE Digital Library.

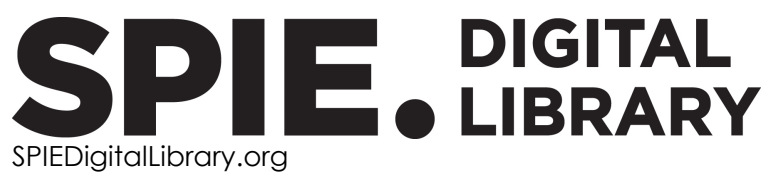

Paper Numbering: Proceedings of SPIE follow an e-First publication model. A unique citation identifier (CID) number is assigned to each article at the time of publication. Utilization of CIDs allows articles to be fully citable as soon as they are published online, and connects the same identifier to all online and print versions of the publication. SPIE uses a seven-digit CID article numbering system structured as follows:

- The first five digits correspond to the SPIE volume number.

- The last two digits indicate publication order within the volume using a Base 36 numbering system employing both numerals and letters. These two-number sets start with $00,01,02,03,04$, 05, 06, 07, 08, 09, OA, OB ... 0Z, followed by 10-1Z, 20-2Z, etc. The CID Number appears on each page of the manuscript. 


\section{Contents}

IR DETECTOR MATERIALS DEVELOPMENTS I

1150306 Graphene photodetector based on interfacial photogating effect with high sensitivity [11503-5]

READ-OUT CIRCUITS AND ALGORITHMS

1150309 Identifying and characterizing blinking pixels in photodiode arrays with hidden Markov models (Invited Paper) [1 1503-8]

11503 OA Development of an algebraic nonuniformity correction algorithm for hexagonally-sampled infrared imagery [1 1503-9]

\section{IR TECHNOLOGY APPLICATIONS I}

11503 OB Infrared sensing technologies assisting environmental monitoring (Invited Paper) [11503-10]

11503 OC Engineering a pulse rate monitoring glove [11503-11]

11503 OD Infrared thermography and machine learning based patient health monitoring [11503-12]

IR DETECTOR MATERIALS DEVELOPMENTS II

$115030 G \quad$ Heteroepitaxial integration of InAs/InAsSb type-II superlattice barrier photodetectors onto silicon [11503-15]

\section{IR DETECTOR TECHNOLOGY}

11503 OJ Mid-IR photodetection by interlayer exciton in 2D heterostructure (Invited Paper) [11503-18]

11503 OK A simple and cost-effective metal coating method for reflective long period grating sensors [11503-19]

$11503 \mathrm{OL} \quad$ GaN/AIGaN avalanche photodiode detector technology for high performance ultraviolet sensing applications [1 1503-20] 
11503 OM Development of high-performance graphene-HgCdTe detector technology for mid-wave infrared applications [1 1503-21]

\section{IR TECHNOLOGY APPLICATIONS II}

11503 ON Development of UV to IR band nanostructured antireflection coating technology for improved detector performance (Invited Paper) [11503-22]

$115030 Q \quad$ Use of infrared imaging in the assessment of breast tuberculosis [11503-25]

$11503 \mathrm{OR}$ Investigation of harmful slip in a rolling bearing using a thermographic camera with a derotator [11503-26]

11503 OS Hallbach array-based linear generator for human motion energy harvesting [11503-38]

\section{POSTER SESSION}

11503 OT A cost-effective alternative for chessboard pattern to calibrate industrial infrared cameras used in defect measurement with active lock-in thermography [11503-27]

11503 OU Drone patrol using thermal imaging for object detection [11503-28]

$11503 \mathrm{OV}$ Optimizing performance of silver-plated silicon photodetector in near infrared band with applied bias [11503-29]

11503 0X Responsivity enhancement of metal/semiconductor Schottky IR photodetector through visible light assistance [11503-31]

1150310 Temperature characteristics of benign and malignant breast pathologies [11503-34]

$1150311 \quad$ Optofluidic gratings used in refractometers [11503-35]

$1150312 \quad$ Electronic, magnetic, and optical properties of $\mathrm{Mn}$ doped $\mathrm{SnO}_{2}$ using Tran-Blaha's modified Becke-Johnson exchange potential: a first principle study [11503-36] 